\title{
Sprawozdanie z sympozjum naukowego "Rozwój małego dziecka - jak i gdzie szukać pomocy", Uniwersytet Medyczny w Poznaniu - Uniwersytet im. A. Mickiewicza w Poznaniu (Poznań, 3 kwietnia 2014 r.)
}

Problematyka rozwoju małego dziecka to temat wielu rozmów specjalistów. Zaburzenia rozwoju dzieci, takie jak autyzm, niepełnosprawność intelektualna czy zaburzenia genetyczne i metaboliczne, są wykrywane u coraz młodszych dzieci. Sympozjum umożliwiło spotkanie się specjalistów z obszaru medycyny ze specjalistami z obszaru psychologii, pedagogiki i logopedii.

Wczesna i prawidłowa diagnoza dziecka oraz wczesne podjęcie oddziaływań terapeutycznych zwiększają szanse na lepsze funkcjonowanie dziecka w środowisku rodzinnym, przedszkolnym, szkolnym, lokalnym. Aby jednak ta diagnoza była prawidłowa, konieczna jest współpraca ze specjalistami z różnych obszarów. Celem sympozjum stało się więc zgromadzenie specjalistów z różnych dziedzin nauki i wspólne wypracowanie postępowania diagnostycznego $\mathrm{w}$ stosunku do małego dziecka przejawiającego zaburzenia w rozwoju.

Po raz pierwszy w Poznaniu odbyło się seminarium naukowe zorganizowane przez Klinikę Psychiatrii Dzieci i Młodzieży - Pracownię Psychopatologii Dziecka Uniwersytetu Medycznego w Poznaniu oraz Zakład Pedagogiki Specjalnej Uniwersytetu im. Adama Mickiewicza w Poznaniu. Sympozjum zorganizowano 3 kwietnia 2014 r. Patronat honorowy objął marszałek województwa wielkopolskiego Marek Woźniak. Patronami byli 
także rektor Uniwersytetu Medycznego oraz dziekan Wydziału Studiów Edukacyjnych. Sympozjum otworzył prof. dr hab. n. med. Andrzej Rajewski, który wprowadził jego uczestników w tematykę spotkania.

Pierwsza sesja sympozjum dotyczyła etiopatogenezy i diagnozy medycznej. Swoje referaty zaprezentowali przedstawiciele Poznańskiego Uniwersytetu Medycznego. Jako pierwszy z referatem „Czynniki stresowe w okresie prenatalnym wpływające na rozwój ośrodkowego układu nerwowego" wystąpił prof. dr hab. n. med. Andrzej Rajewski. Jak podkreślił prelegent, liczne badania wskazują na to, że silny i długotrwały stres doświadczany przez matkę $\mathrm{w}$ trakcie ciąży ma wpływ na zmiany zachodzące w układzie nerwowym płodu, m.in. na zmianę neuroprzekaźników w mózgu oraz inne nieprawidłowości.

Kolejny referat zaprezentowała dr hab. n. med. Agnieszka Słopień. W wystąpieniu "Zmiany zaproponowane w klasyfikacji DSM5 - rozwój mowy, niepełnosprawność intelektualna, spektrum autyzmu" prelegentka wskazała, jakie przeobrażenia zaszły w omawianej klasyfikacji w porównaniu z jej wcześniejszym wydaniem. Szczególnie istotne zmiany wydają się dotyczyć redefinicji autyzmu oraz podejścia do diagnozy tego zaburzenia.

Kolejne trzy wystąpienia dotyczyły specjalistycznej diagnostyki medycznej w obszarze genetycznym, neurologicznym i metabolicznym. Prof. dr hab. n. med. Anna Latos-Bieleńska przedstawiła referat „Wskazania do diagnostyki genetycznej $\mathrm{w}$ obserwowanych zaburzeniach rozwoju dziecka". Zwróciła w nim uwagę na to, że diagnostyka genetyczna jest bardzo ważna i konieczna. Wskazała sytuacje, w których należy skierować dziecko na takie badanie. Przedstawiła także liczne przykłady rzadkich zaburzeń genetycznych mogących wiązać się z niepełnosprawnością intelektualną dziecka oraz inne, bardziej znane zespoły genetyczne.

Prof. dr hab. n. med. Barbara Steinborn zaprezentowała referat „Wskazania do diagnostyki neurologicznej $\mathrm{w}$ przypadku zaburzonego rozwoju dziecka". Podobnie jak jej przedmówczyni, zwróciła uwagę na to, jakie objawy u dziecka powinny być przesłankami do poszerzenia diagnostyki $\mathrm{w}$ obszarze neurologii. Wskazała także, jakie konsekwencje $\mathrm{w}$ rozwoju mogą spowodować padaczki pojawiające się u małych dzieci.

Dr Łukasz Kałużny zaprezentował referat „Wskazania do diagnostyki w kierunku chorób metabolicznych w przypadku zaburzonego rozwoju dziecka". Obszar ten jest ciągle mało poznany przez specjalistów zajmujących się diagnostyką małych dzieci. Prelegent podał przykłady chorób 
metabolicznych, które mogą występować u dzieci, oraz ich konsekwencje w sytuacji późnego rozpoznania. Podkreślił ogromną ważność diagnostyki u dzieci w tym obszarze.

Po przerwie odbyły się warsztaty „Diagnoza zaburzeń rozwoju w praktyce - dokumentacja filmowa", przygotowane przez dr Anetę Wojciechowską oraz dr hab. n. med. Agnieszkę Słopień. W trakcie warsztatów zaprezentowano nagrania wideo pokazujące rozwój dziecka od pierwszych miesięcy życia do okresu wczesnoszkolnego w różnych obszarach: rozwoju ruchowego, komunikacji, społecznego oraz poznawczego. W filmach wskazano zarówno prawidłowe zachowania w rozwoju, jak i takie, które mogą świadczyć o zaburzeniach, szczególnie ze spektrum autyzmu.

W kolejnej części, zatytułowanej „Diagnoza psychologiczna, pedagogiczna i logopedyczna", wystąpili przedstawiciele ośrodków akademickich oraz placówek, które zajmują się diagnozą małego dziecka w praktyce.

Natalia Juchniewicz (Stowarzyszenie na rzecz Osób z Autyzmem ProFUTURO w Poznaniu), Joanna Lisiak (Poradnia Psychologiczno-Pedagogiczna nr 1 w Poznaniu), Ewa Szymańska (Poradnia Psychologiczno-Pedagogiczna nr $1 \mathrm{w}$ Poznaniu) oraz Joanna Świątkowska (Poradnia Psychologiczno-Pedagogiczna nr 1 w Poznaniu) w wystąpieniu „Narzędzia badawcze stosowane w diagnozie rozwoju małego dziecka" oraz dr Marzena Buchnat (Zakład Pedagogiki Specjalnej UAM Poznań) i dr Magdalena Stawicka (Fundacja Zero-Pięć) w prelekcji „Diagnoza psychologiczno-pedagogiczna dziecka $\mathrm{z}$ zaburzonym rozwojem - $\mathrm{z}$ uwzględnieniem narzędzi badawczych" omówiły narzędzia wykorzystywane do diagnozy psychologicznej funkcji poznawczych oraz do diagnozy pedagogicznej.

W sekcji tej pojawiło się także wystąpienie dotyczące diagnozy logopedycznej i różnicowania autyzmu od zaburzeń mowy u dzieci. Był to referat dr Anety Wojciechowskiej (Zakład Pedagogiki Specjalnej UAM) zatytułowany "Zaburzenia rozwoju mowy a spektrum autyzmu”. Dr Izabela Kaczmarek (Pracownia Psychologii Dzieci i Młodzieży - Szpital Kliniczny w Poznaniu) zaprezentowała pracę „Diagnoza neuropsychologiczna", w której podjęła rozważania nad związkiem między układem nerwowym a procesami poznawczymi.

Ostatnie wystąpienie, zaprezentowane przez dr Annę Gulczyńską (Pracownia Edukacji Zdrowotnej UAM), miało tytuł „Funkcjonowanie dorosłego w kontekście zaburzeń komunikacji społecznej" i dotyczyło perspektywy osoby dorosłej w kontekście trudności komunikacyjnych. Prelegentka wskazała, jakie konsekwencje w zaburzonym rozwoju teorii 
umysłu mogą pojawić się w funkcjonowaniu społecznym osoby dorosłej i jak istotne jest znaczenie treningu społecznego już od najmłodszych lat.

Obrady sympozjum „Rozwój małego dziecka - jak i gdzie szukać pomocy" oficjalnie zamknął prof. dr hab. n. med. Andrzej Rajewski. 